\title{
Increasing Social Relations Quality by Socioemotional Selectivity of Elderly at PERWAJAS Community
}

\author{
Stefanny Eveline ${ }^{1}$, Rustono Farady Marta ${ }^{2}$, Joshua Fernando ${ }^{3}$, Irmawan Rahyadi ${ }^{4}$, Siti \\ Nur'Aini ${ }^{5}$ \\ Universitas Bunda Mulia, Jln. Lodan Raya No. 2, North Jakarta, 14430, Indonesia ${ }^{1,2}$, Universitas Mpu \\ Tantular, Jln. Cipinang Besar No.2, East Jakarta, 13410, Indonesia ${ }^{3}$, Bina Nusantara University, Jln. \\ Kebon Jeruk No. 27, West Jakarta, 11480, Indonesia ${ }^{4}$, Universitas PGRI Semarang, Jln. Sidodadi Timur \\ No 24 - Dr. Cipto, Semarang, Central Java, 50125, Indonesia ${ }^{5}$
}

stefannyeveline0710@gmail.com ${ }^{1}$, rmarta@bundamulia.ac.id ${ }^{2}$, joshuafernandosaty@gmail.com ${ }^{3}$,
irmawan.rahyadi@binus.edu ${ }^{4}$, sitinuraini@upgris.ac.id

\begin{abstract}
The elderly is a critical, transitional, and regressive period which is marked by a setback to the physical, mental, and intellectual ability. These symptoms cause the elderly to have difficulties in understanding and interacting with people, but the elderly migrants from the West Kalimantan Jamthang and Asin Residents Association (PERWAJAS) community can show a contrasting reality from the existing stigma. PERWAJAS is a community of immigrants living in West Kalimantan who have entered the early and late stages of the elderly. Negative stigma about the elderly that has been circulating in the community seems to contradict the reality drawn through the activities and work programs of the PERWAJAS community. This qualitative study uses an interpretive approach and is implementing the socioemotional selectivity theory. The results of this study found that communication has a vital role in the PERWAJAS community amid physical and mental deterioration. However, they can adapt to their condition to produce the potential to develop skills, productivity, and improve the quality of social relations.
\end{abstract}

Keywords: Elderly, PERWAJAS Community, Socioemotional Selecvity, Social Relations

\section{Introduction}

The elderly is a critical period where the elderly evaluate the past, live the present while preparing for the future. The elderly period is defined as a transitional period where a person experiences change not only physically but also in social roles, which then influence social relations and setbacks, which subsequently play a role in the deterioration of social roles [1].

The elderly period is transitional and regressive, characterized not only by physical setbacks but also by mental setbacks, which play a role in the deterioration of social roles [2]. Mental deterioration itself is part of the aging process that people between the age of 45 to 55 years old are experiencing. If the elderly are unable to adapt, then they will not survive a challenging ecological environment, which later, it has an impact on the appearance of psychological disorders and decreased social participation[3].

In addition to the decrease in intellectual capabilities that make it difficult for older people to understand and interact, the reduced ability to adjust to a new environment is also one of the characteristics of the elderly [4]. The rise of negative stigma about the elderly also has an impact on reducing the desire to carry out social interactions [5]. 


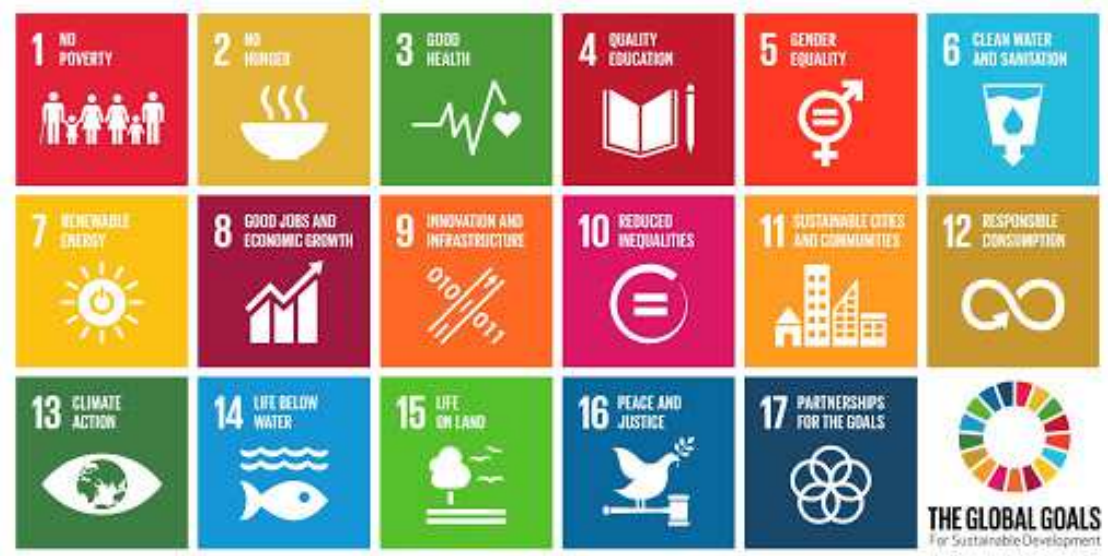

Fig. 1. SDGs Goal

As Seen in Fig 1 [6] the vision to pay attention to the elderly has become part of Sustainability Development Goal number 10, namely reducing inequality. The presence of caring communities and even elderly members help to achieve the goals of reducing the existing inequality [7]. To reduce the imbalance of minorities such as the elderly, PERWAJAS exists as one of the elderly mobilizing communities in Jakarta [8].

The West Kalimantan Jamthang and Asin Residents Association is known as PERWAJAS, which was spearheaded by several Jamthang overseas community leaders in Jakarta. The community covers the areas of Kaliasin, Sedau, Lirang, Saliung, Sip Sam Hong, Sakok, and Kopisan in West Kalimantan. It was officially founded on May 30, 2017, and currently is dominated by pre-elderly and elderly who often meet to discuss matters they consider crucial and be socially active in planning. Their activities intend to support education and health development in West Kalimantan.

The members of the PERWAJAS community are immigrants living in Jakarta. However, although they have interacted with the new environment, it does not necessarily mean that they lose their old identity [9]. The cultural identity, which is part of the identity of members, becomes an encouragement for the elderly to remain productive in old age by forming a community to achieve emotional satisfaction.

Socioemotional selectivity theory describes the age-associated with increased motivation to conduct activities oriented to emotional satisfaction and decreased motivation in gathering information to broaden insight [10]. The Socioemotional selectivity theory also states that time perspective is integrally involved in behavior directed at personal goals and motivation. The perceived time limitation and the remaining time in life are related to one is becoming more selective in investing resources and leading to changes in motivation and attention to activities that are emotionally meaningful or to achieve emotional satisfaction [11].

At the beginning of life, when time is still long, individuals will be motivated to prepare for a long and mysterious future. This orientation encourages individuals and will allocate considerable resources to acquire knowledge, develop new skills, and be motivated to do so, mainly when knowledge is limited because the struggle for knowledge is crucial from late adolescence to middle adulthood [12].

This study aims to look further at the construction of the awareness of the elderly who are members of the PERWAJAS community. The benefits of this research are expected to be a 
trigger for the reduction in the application of Ageism or discrimination prejudice that is usually directed at older people based on age, and see how the PERWAJAS community can help the elderly to have more productive awareness in their old age. It is also hoped that the results of this research can be the foundation for creating an appropriate intervention to help the elderly in dealing with aging and create a more active and healthier elderly both physically and psychologically so that later it affects the increasing ability of the elderly to communicate and adapt.

\section{Method}

The research uses a qualitative approach and the interpretive paradigm [13]. The results of the study are based on a perspective that relies on the goal of understanding and describing the social world from the individuals involved in it and focusing on the process of shaping human knowledge through social interaction [14].

Research has been conducted from January to May 2019. Researchers have collected primary data through in-depth interview techniques [15]. On the other hand, secondary data through literature study techniques, and the use of documents such as Hallo Kalimantan magazine edition 24 / IV / August 2018 to get additional information about the PERWAJAS community to get a broad and in-depth overview and to learn in detail the historical and cultural events of the PERWAJAS community which then produce a picture of the journey of the members concerned. The research subjects were selected with specific criteria and related to the issues raised by the researchers, which are potential elderly people who have entered the early elderly and late elderly, namely from the age of 46 - 65 years who are members of PERWAJAS.

\section{Result And Discussion}

The West Kalimantan Jamthang and Asin Residents Association (PERWAJAS) was founded in 2017 and was dominated by potential elderly members aged 45-65 years. Despite their age, they did not consider it an obstacle to staying healthy, being independent, and actively communicating support for improving the quality of their life and others, especially the lives of fellow seniors, although in general, age was inversely proportional to social participation [16].

The PERWAJAS community did not accept members who were not from West Kalimantan. As a written principle in the PERWAJAS, the third point of the terms and conditions of membership declared such limitation. A person who wished to be part of the community had to be blood-related to the individuals or citizens from the Kaliasin, Sedau, Lirang, Saliung, Sip Sam Hong, Sakok, and Kopisan areas in West Kalimantan. The decision to limit outsiders off the community was to maintain the cultural identity, which was in line with the elements in the theory of Social Selectivity.

This phenomenon also improved the way people out look at the elderly, broke the chain of inequality in the assessment of the elderly, and broke the negative assumptions that developed in society such as the elderly were considered as unproductive, weak, and less independent. 


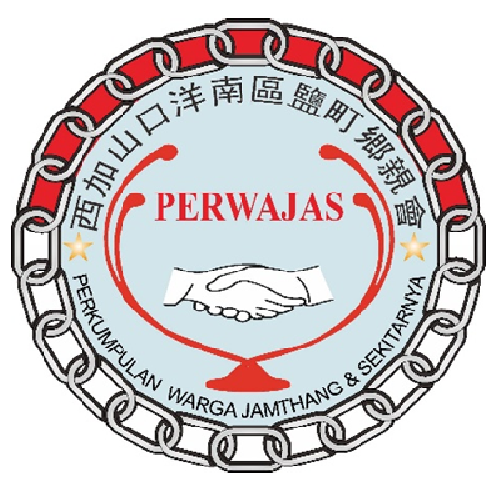

Fig. 2. PERWAAS Logo

Although changes in physical health, financial status or social adjustments experienced in the elderly are more challenging than those faced at other stages, the PERWAJAS community which is dominated by elderly members has the potential to illustrate that age is not an obstacle to remain healthy, independent, and actively communicate support for improving the quality of life of themselves and others, especially fellow seniors, although in general aging is inversely proportional to social participation [16]. This phenomenon also improved the way people looked at the elderly, who generally tended to be reluctant to participate and engage in social activities due to physical or mental limitations.

One of the efforts to alleviate the challenges of being old is by making an organization whose members are the people who have the same interest and background, as expressed in the narrative below:

"Initially, because I wanted to give the last respect to the family of a friend who died ... he came from Kalimantan and had only just moved to Jakarta, and at the same time wanted to chat and meet with old friends to be good ... right after chatting, it turned out that my friends had stories. many people are sick, there is no cost in Kalimantan so what if we join joint ventures to make associations ")(Ceu Cen Khiong, 60 Years, Entrepreneur)

Based on the answer from Ceu Cen Khiong, it could be seen that what underlies his desire to form the PERWAJAS community was to establish communication with friends whose family member had died. Consequently, he invited other friends to be present during the night of flowers - a funeral ceremony- to give the last honor while maintaining good relations.

The communication element captured how communication skills encouraged the elderly to adapt and vice versa. Through the process of adaptation, communication skills had increased and improved. It could be seen that the challenges caused by the increased age affect the productivity of the elderly. The elderly who did the activities expressed that they had successfully adapted to a challenging ecological environment. They believed that those who could adapt were those who would survive in a challenging ecological environment.

"PERWAJAS is there so that it is easy for communication between the villagers and overseas in Jakarta, I am invited to join ... because I know I want it ... if it's like a birthday and the donation that I have ever had there was one person from our village, I helped it so it was so happy can help people "(Ng Bui That, 59 Years, Entrepreneur) 
The motivation of $\mathrm{Ng}$ Bui to join the PERWAJAS community was because he got invited, and he knew some other members. Besides, he wanted to participate by contributing to financial donations for villagers in need. The meeting finally led to a collaboration that produced creativity to generate ideas in helping fellow seniors [18].

"In the beginning, we people wanted to gather, but it was hard to meet, finally we took the initiative of gathering citizens to meet, then after a few times, the result was that we wanted to create a group in WA, and finally, there were other initiatives, some residents wanted to form this association. After being discussed in the meeting, PERWAJAS was finally formed "(Cong Ket Lun, 50 Years, Entrepreneur)

Using social media technology made the grouping of information fast so that PERWAJAS was formed [19]. Another success story was how quickly they adapt to the organization because they shared the same language, making it easier to communicate and express opinions and ideas. The interaction contributed to the improvement of the communication skills of the elderly, as expressed by the elderly in the PERWAJAS community during the interview process. These findings were in line with the idea of Socioemotional selectivity in an organization or group where satisfaction was not possible without fulfilling two conditions, namely, social contact and communication [20].

The communication element understood was used to describe the organization's process of gathering and understanding information in the PERWAJAS community through discussion activities, both face-to-face and through the media. The adaptation itself was mainly a process of fulfilling the conditions for sustaining life. One of these conditions was a social condition where humans needed relationships to be able to carry out orders not to feel excluded [1]. The established relationships were manifested in actions in the community that was mutual help between members.

"Yes, for example, a family member is sick ... do not have funds, from the management we gather ... the people in this management are mostly successful, so they can help those who are sick ... it is like helping families, both from Jamthang kankalo, someone died yes we stop by .. last respect .. if someone is sick we give a little compensation as we can .. "( $\mathrm{g}$ Sun Cuk, 58 Years, Entrepreneur)

$\mathrm{Ng}$ Sun Cuk considered the people who came from Jamthang or his hometown as family. He did not hesitate to provide moral support during the death of a family member. He also provides financial support for the villagers who need medical treatment.

Another form of activity is carried out by the Elderly-Friendly Indonesian community, which provides programs to help improve the value of a life of the elderly in various regions, one of which is Depok.

"Yes, if based on my experience ... for example, we make an old school program in a certain area, most participants also know each other ... it helps the elderly in adapting and receiving information ... such as bonding, not feeling alone ... and feel they have someone with the same condition ... "(Andi Bahtiar, 28 years old, Comdev Manager of Indonesia Friendly Elderly Branch of Depok)

Based on his experience in holding various social activities for the elderly, Andi argued that one of the factors that had the potential to encourage the elderly to actively participate was 
to know one another among the elderly. From the interaction and sharing the same feeling that they had the same conditions, it would lead to the process of adapting. Thus, receiving and sharing the information would feel easier because they experienced it together.

The adaptation element, in this case, considers that humans tended to produce improvements towards something higher. They hoped to experience a better way of life to survive in a challenging ecological environment. The tendency and expectation were in line with the results of the research. It showed that research subjects wanted to live better life through interactions in the form of social contact and communication. The opinion was a development from what was said during the interview where they disclosed their physical and mental setbacks because of their age, and they believed that they could overcome all these obstacles.

The illustration from the Chairperson of PERWAJAS supports the notion that health problems were not a hindrance. The chairperson admitted that he was not well-educated, and in terms of health, he was not in his prime condition. He had had open-heart surgery to install a ring. However, his health condition did not stop him from performing and becoming a productive and motivated individual. In the interview process with the topic of communication dynamics, they also said that their communication skills were not very good before joining the PERWAJAS community.

Socioemotional selectivity theory looks deeper into one of the characteristics of old age, where they had a desire to gain meaning and satisfaction in life. This theory was in line with the results of research that showed that the elderly and elderly from the PERWAJAS community felt happy and satisfied with their old age because they could help others. The activities they do were also not material-oriented, and there was no financial benefit, but they got meaningful emotional ties and the quality of social relationships.

The increasingly limited time to live also caused the pre-elderly and the elderly to be more selective in investing resources. Pre-elderly and elderly in the PERWAJAS community preferred to invest resources in emotionally meaningful activities. They provided health benefits, gave donations for school construction in West Kalimantan, and took time to pay their last respects to the family members of the deceased. They opted to do those activities rather than learning new things because as they got older, the time available to acquire and take real benefits related to knowledge was also less.

It as undeniable that as long as they were members of the PERWAJAS community, their communication skills and insights improved. However, this increase was not the main thing that encouraged informants to form the PERWAJAS community. The results of the discussion on this element were revealed through questions in the interview process with the elderly topic.

Early in life, the pre-elderly and the elderly in the PERWAJAS community were motivated to gain knowledge to broaden their horizons and prepare for a long and mysterious future. This was evidenced by some of those who become traders and made as much money as possible to meet all the needs in life. However, when they were successful and entered old age, they tended to choose to share the results of their work they did at a young age with people who were more in need.

The results of research that could also be understood through the motivational element in Socioemotional selectivity theory were people who entered old age were not only satisfied when successfully having a social network with emotional closeness, but they were also actively involved in the process of formation. From the narrative of the board of directors in the PERWAJAS community, it was summarized that establishing communication and building good relations with other overseas friends were not only built by meeting and communication 
but also by formally forming an association with a clear vision, mission, structure, and program. One element in Socioemotional selectivity theory considered that the network consisted of partners that he knew and was emotionally close [21]. This was in line with the results of research that showed that the elderly and elderly in the PERWAJAS community tended to help villagers because they felt familiar and had emotional closeness.

\section{Conclusion}

Research has involved pre-elderly and elderly in the PERWAJAS community has produced new images and insights that are contrary to the stigma, myths, and negative stereotypes that already exist for the elderly. Although the development of the elderly is indeed regressive, this study found many other factors that encourage related subjects to remain productive in producing goods and services. These factors are understadable through adaptation and communication that focus on behavioral change are results of successful of survival in an ecological environment, as well as the socioemotional selectivity theory with elements of age, motivation and cultural identity that focus on shifting motivation with emotional satisfaction orientation due to aging.

In the communication process, there are dynamics in the form of encouragement or obstacles that affect the quality of communication. However, if the initiator of communication, in this case, are pre-elderly and elderly in the PERWAJAS community can adapt to physical and mental setbacks and have high motivation to obtain emotional meaning then they still have the potential to develop skills including communication skills and improve quality through social relationships that have been was built.

\section{References}

[1] Ayu Diah Amalia, "Kesepian dan Isolasi Sosial yang Dialami Lanjut Usia: Tinjauan dari Perspektif Sosiologi," Informasi, vol. 18, no. 02, pp. 203-210, 2013.

[2] Livana, Y. Susanti, L. E. Darwati, and R. Anggraeni, "Gambaran Tingkat Depresi Lansia," J. Keperawatan dan Pemikir. Ilm., vol. 4, no. 4, pp. 80-93, 2018.

[3] L. M. L. Sangian, F. Wowiling, and R. Malara, "Hubungan Dukungan Emosional Keluarga dengan Penerimaan Diri pada Lansia di Desa Watutumou III," e-Jurnal Keperawatan, vol. 53, no. 9, pp. 1689-1699, 2015.

[4] E. . Hurlock, Psikologi Perkembangan, 5th ed. Erlangga, 2017.

[5] C. . Miller, Nursing for Wellness in Older Adults, 6th ed. Philadelphia: Lippincott Wiliams \& Wilkins, 2012.

[6] J. Fernando, M. Sya, and R. F. Marta, “Amalgamation as a Strengthening Ethic," Mimb. J. Sos. dan Pembang., vol. 35, no. 2, pp. 334-341, 2019.

[7] K. Muff, A. Kapalka, and T. Dyllick, "The Gap Frame - Translating the SDGs into relevant national grand challenges for strategic business opportunities," Int. J. Manag. Educ., vol. 15, no. 2, pp. 363-383, 2017.

[8] J. Basyir, R. F. Marta, and Y. B. Setiawan, "Redefining the relationship of majority and minority as a social principle," Emerging Trends in Psychology, Law, Communication Studies, Culture, Religion, and Literature in the Global Digital Revolution. pp. 60-63, 2020.

[9] F. Iqbal, "Komunikasi dalam adaptasi budaya (Studi Deskriptif pada Mahasiswa Fakultas Ilmu Sosial dan Humaniora UIN Sunan Kalijaga Yogyakarta),” J. Komun. PROFETIK, vol. 7, no. 2, pp. 65-76, 2014. 
[10] M. J. Van Der Goot, N. Bol, and J. C. M. Van Weert, "Translating socioemotional selectivity theory into persuasive communication: Conceptualizing and operationalizing emotionallymeaningful versus knowledge-related appeals," Int. J. Commun., vol. 13, pp. 1416-1437, 2019.

[11] J. N. Cleveland, L. A. Huebner, K. J. Anderson, and D. V. Agbeke, Lifespan perspectives on job performance, performance appraisal/management and creative performance. Elsevier Inc., 2019.

[12] S. J. Sullivan-Singh, A. L. Stanton, and C. A. Low, "Living with limited time: Socioemotional selectivity theory in the context of health adversity," J. Pers. Soc. Psychol., vol. 108, no. 6, pp. 900-916, 2015.

[13] H. Minhat, "An overview on the methods of interviews in qualitative research," Int. J. Public Heal. Clin. Sci., vol. 2, no. 1, pp. 2289-7577, 2015.

[14] R. F. Marta and J. Fernando, "Dialectics of Forgiveness between Ethnic Communities for West Kalimantan Harmony," J. Messenger, vol. 12, no. 1, pp. 1-13, 2020.

[15] J. Minikel-Lacocque, "The Affect-Responsive Interview and In-Depth Interviewing: What We Can Learn From Therapy Research," Qual. Inq., vol. 25, no. 9-10, pp. 1039-1046, 2019.

[16] E. . Hurlock, Psikologi Perkembangan: Suatu Pendekatan Sepanjang Rentang Kehidupan. Jakarta: Erlangga, 2011.

[17] M. Akbar, "Kajian Terhadap Revisi Undang-Undang No.13 Tahun 1998 Tentag Kesejahteraan Sosial Lanjut Usia,” J. Mimb. Kesejaht. Sos., vol. 2, no. 2, pp. 30-39, 2019.

[18] M. Chinmi, R. F. Marta, C. G. Haryono, J. Fernando, and J. K. Goswami, "Exploring Online News as Comparative Sudy Between Vendatu at India and Ruangguru from Indonesia in COVID-19,” J. Content, Community Commun., vol. 11, no. 6, pp. 167-176, 2020.

[19] F. Nurrahmi, J. Sari, R. F. Marta, Y. B. Setiawan, and R. Rahim, "Aceh young users purchase intention by online store exposure on Facebook," Int. J. Data Netw. Sci., vol. 2, pp. 41-48, 2018.

[20] P. Suparlan, Pengantar Metode Penelitian Suatu Pendekatan Kualitatif. Pontianak: STAIN Pontianak, 1993.

[21] S. A. Moss and S. G. Wilson, "Why Are Older People Often So Responsible and Considerate Even When Their Future Seems Limited? A Systematic Review," Int. J. Aging Hum. Dev., vol. 86, no. 1, pp. 82-108, 2018. 